\title{
Dispersal centers of the Amazonian acridids
}

\author{
C. Amédégnato (') \\ M. Descamps (')
}

\begin{abstract}
The dispersal centers of the Amazonian acridid arboreal fauna are defined on the basis of the study of the subfamilies Bactrophorinae and Proctolabinae. Four dispersal centers are revealed which correspond to the main centers proposed by Müller (1973) and Haf. fer (1979). The ecological characteristics of their fauna and the relations between the centers are tentatively approached through the study of some polycentric distribuition patterns (Ommatolampinae, Proctolabinae). as well as through the more restricted relations between the Amazonian centers and the Atlantic Forest.
\end{abstract}

\section{INTRODUCTION}

One of the most striking features of the Amazonian forest fauna is its extraordinary richness, as is recognized by all the specialists who have undertaken its study. Although often considered as typical open-biotope insects, the acridids $\left({ }^{2}\right)$ also greatly contribute to this wealth, and such a diversity of acridid species cannot be observed anywhere else in the world: 7 species of the genus Poecilocloeus and 5 of the genus Dendrophilacris at Benjamin Constant; 6 Adrolampis and 6 Poecilocloeus at Colonia; and it would be possible to cite many other examples. This uncomparable richness is related to a more important species diversity of the New World compared to that of the Old Worid, and is particularly characteristic of recent fractions of old American acridid groups or of insects newly implanted in South America. However, this species diversity is much more noticeable in forest groups, whose biotope is richer in potential biological isolating mechanisms, than in open-biotope groups.
Through a comparative study of several acridid arboreal populations (Amédégnato \& Descamps, 1981), the basic faunal components were brought to light. Whatever the origin of the samples, the composition of the arboreal fauna is the same and contains four principal components (Bactrophorinae, Ommatolampinae, Proctolabinae, and Romaleinae) which represent by ihemselves 74 to $84 \%$ of the species and 84 to $92 \%$ of the individuals. Each one of these subfamilies includes groups of genera that exhibit different and often opposite ecological valonces. Their representation in the different sampels is related to their geographic location, to the forest types, and to the state of degradation of the forest.

In order to define the principal distribution centers of the Amazonian acridids, in this study we will mainly use two of the most important arbo:eai groups that have recently been revised: the Bactrophorinae (Descamps, 1978, s/d) and the Proctolabinae (Descamps, 1976. 1980) .

The Bactrophorinae account for 31 to $47 \%$ of the individuais and 35 to $40 \%$ of the species that make up the acridid arboreal fauna. This subfamily displays a relatively archaic structure of the genitalia which indicates that they originated from a very ancient stock of Acridoidea, and includes the most primitive members of the Piomaleidae, a typically American family. However, most of the Amazonian genera, highly adapted to arboreal life and strictly linked to the forest, belong to a comparatively recent fraction of this subfamily, currently undergoing very intense speciation. Some of

(1) - Laboratoire d'Entomologie, Muséum National d'Histoire Naturelle, Paris.

(2) - Systematic place of species, definition of groups of genera, tribes and subfamilies, and their phylogenetic relationships are given in the following systematic papers: Amedegnato, 1977, Carbonell \& Descamps, 1973, Descamps, 1976, 1973, 1980 and in press. 
its primitive Andean members (Taeniophorini, Lagarolampae) overlap the Amazonian basin. but they are limited to the western region.

The Proctolabinae are less important and account for oniy 6 to $14 \%$ of the individuals and 13 to $26 \%$ of the species that comprise the acridid arboreal fauna. Contrary to the Bactrophorinae, this subfamily is more highly evolved and recently arose in the tropical part of North and Central America, diverging from a typically Old World branch (Amédégnato, 1977). The Proctolabinae came only recently to South America where their members, less adapted to the forest and more vagile than the Bactrophorinae, are often characteristic of secondary formations or of forest edges and exhibit a great diversity of species characterized by hypertelic of genitalia.

\section{METHODS}

In order to separate and characterize the different regicnal faunas within the Amazonian fauna, we used the following taxonomic categories :

- monospecific and limited-species gene$r a$, endemic in parts of the Amazonian basin;

- groups of closely related species until now only known by punctual or quasi-punctual signalizations; bution;

- species with a medium-range distri-

- subspecies, used in a few cases.

The use of such different categories may at first seem surprising, but in a preliminary study any local originality (from morphs or chromatic types to genera) is useful in distinguishing a biogeographical entity.

For a given group and for each taxonomic level, all the known signalizations were mapped and the resulting figures were superimposed. The Bactrophorinae (124 species) and the Proctolabinae (77 species) were treated separately. In both cases, four zones of maximum superimposition were revealed (fig. 1.2). For both subfamilies, the contours of these zones delimit the distribution area of the endemic elements that characterize each dispersal center. Some polycentric distributions also appeared, and they will be studied in the section dealing with faunistic relations between centers. The consistency of the results confirms that the use of different taxonomic levels is fully justified.

\section{Dispersal Centers}

The four dispersal centers defined in the above manner are almost the same as those recognized by Müller (1973) for terrestrial vertebrates. We will, therefore keep his terminology. However, Müller differentiates a fift $h$ center (Pará), located to the east of the Rio Tocantins, a region for which we have no information on the groups concerned.

The two western centers, Napo in the north and Ucayali in the south, are clearly differentiated for the Bactrophorinae (Fig. 1) . However, with regard to the Proctolabinae (Fig. 2), the Amazonian occidental fauna is more homogeneous (greater number of species common to both centers) .

This difference is probably related to the fact that the Proctolabinae are in general less strictly arboreal and more vagile than the Bactrophorinae. It therefore seems more sound to consider, like Müller (lbid.), that the two western centers are parts of one large West Amazonian center limited by the Andes, the Rio Negro, and the Rio Madeira. The species which could not be related to groups typical of one of these subcenters represent $27,6 \%$ of the Bactrophorinae and $66,6 \%$ of the Proctolabinae.

The two eastern centers, Guianan in the north and Madeira in the south, certainly have some elements in common but they are quite clearly differentiated (only 2 species in common for the groups studied).

These results also agree with those of Haffer (1979) who recognized six dispersal centers for birds. Four of them correspond to our divisions, the fifth is the Pará center which is also distinguished by Müller (Ibid.), and the sixth is located between our two septentrional centers. The two centers that are not differentiated for acridics represent regions for which we have very little data. They are : 


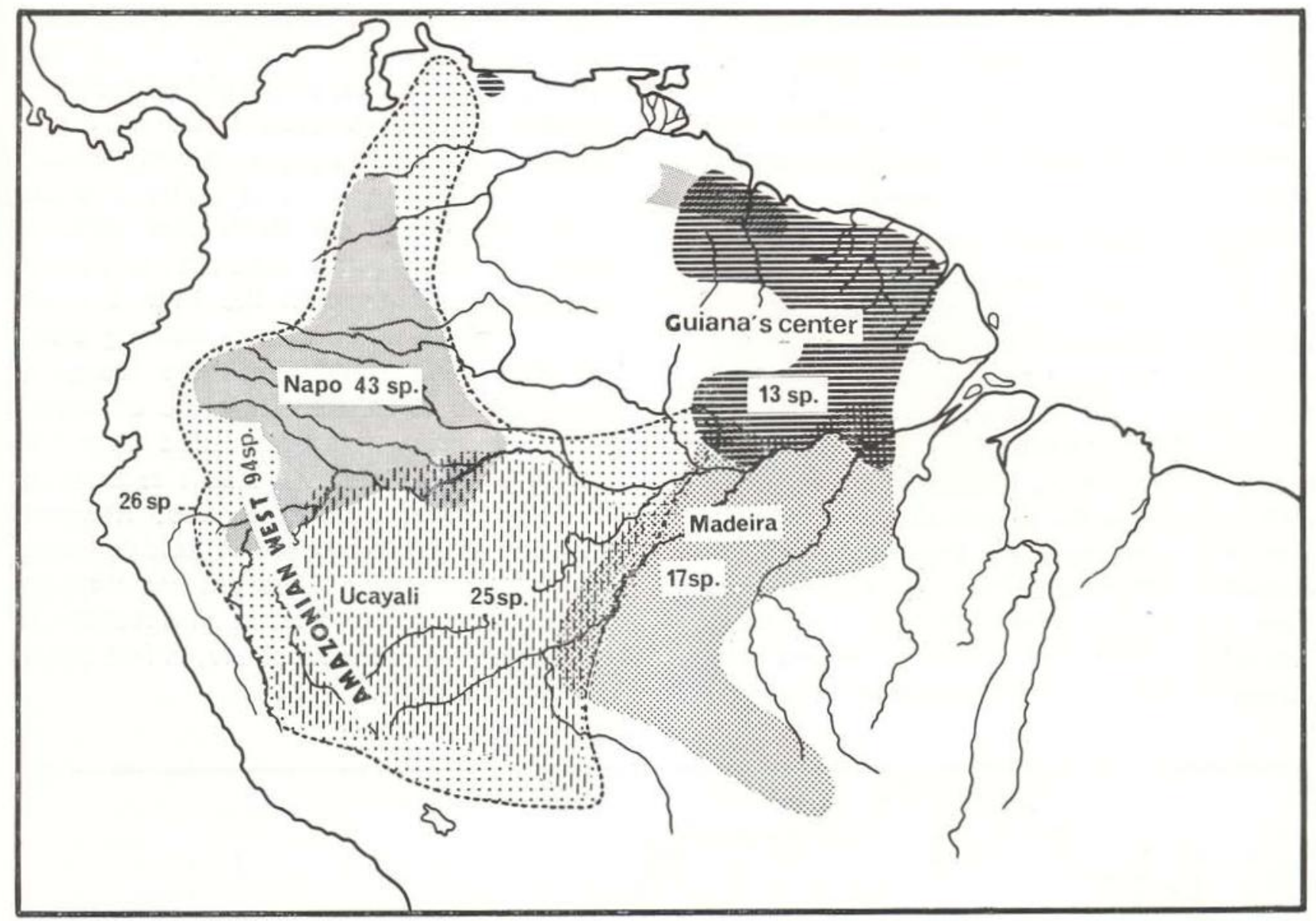

Fig. 1 - The dispersal centers of the Bactrophorinae.

1) The region south of the Lower Amazon between the Rio Xingu and the Atlantic coast.

2) The Venezuelan and the Rio Negro regions.

\section{OVERLAPPING}

Besides a widespread distribution (especially concerning the species or groups of species of the western-center Proctolabinae and Bactrophorinae) which probably represents ancient overlappings followed by successful adaptation, boundary overlappings clearly exist between the four centers. They are apparently located along the most important rivers (Amazon, Rio Madeira, and Rio Negro) and affect $5,4 \%$ of the species studied (11 out of 201 species of Bactrophorinae and Proctolabinae $\left({ }^{3}\right)$. Moreover, we observed 22 cases of overlapping at the higher level of groups of parent species (i. e., with allopatric speciation between the centers). This concerned primarily the Bactrophorinae. But, the present state of our knowledge does not allow us to say if the fiuvial barrier is really a more effective factor of differentiation than the distance between stations within a given center, for as in a great number of cases, each station is characterizzd by its own form.

These boundary overlappings appear on the maps to be limited to the main rivers, but as most of the samples that enabled us to detect them were located along these barriers, the

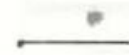

(3) - 7 species of this group are known only from Benjamin Constant and Tabatinga and, therefore, cannot be assigned to one of the centers. This explains why center overlapping does not appear on the map (Fig. 2). 
true range of these overlappings remains largely unknown. However, the sample from Jutai, located half-way between Madeira and Purus, sesms to show that the boundary overlappings may be wide and are probably greatly dependent on species or groups.

Despite these marked overlappings, it seems that rivers do function somewhat as obstacles to dispersal. This is particularly true for the less vagile Bactrophorinae in which were found, among the 33 cases cited above, most of the differences and conversely the smallest number of the similarities. The wide distribution of most of the species of Proctolabinae compensates for the apparent lack of an Upper Amazonian overlapping. Even of the rivers constitute effective barriers to dispersal, we must note that along the Rio Madeira, the Rio Negro, and the Lower Amazon, they are reinforced by heterogeneous bands in which the forest is interspersed with areas of less-dense vegetation (campos cerrados, campinas) . These zones, winich subsist in fact as ecologica! barriers, must have been much more pronounced during the Quaternary xeric periods and were obviously more effective obstacles to the dispersal of the fauna than were the rivers. Such a structure does not exist in the zone of contact between the Napo and the Ucayali centers where climate and vegetation are similar. As a result of these ecological conditions, it is coherent that the oscidental faunas are more closely related than the oriental and the occidental faunas or those of the Madeira and Guianan centers. However, the barrier zones comprised of heterogeneous vegetation and major rivers are not absolute, for the insects cross them in all directions in the overlapping zones which are, in fact, zones of Interpenetration.

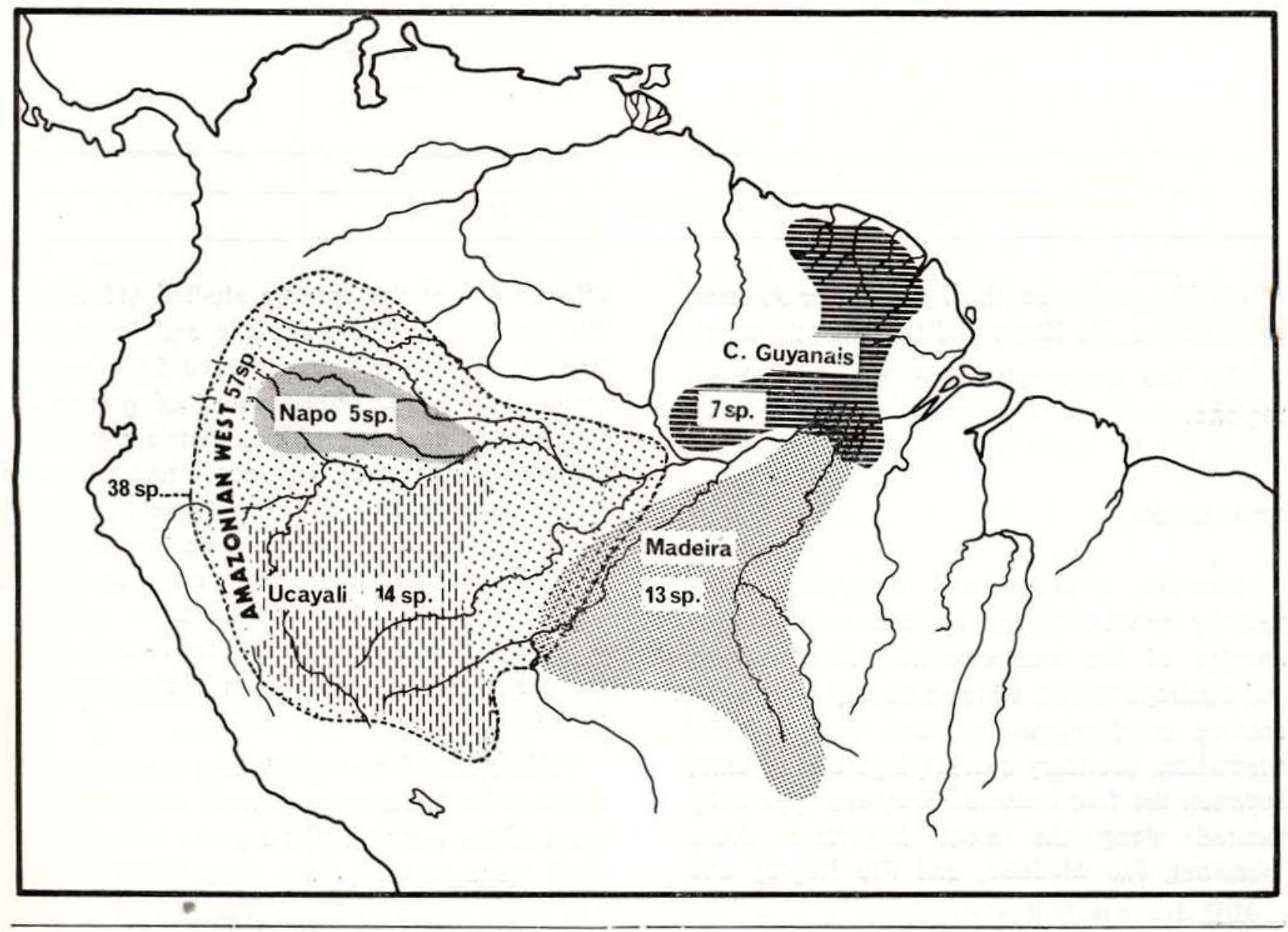

Fig. 2 - The dispersal centers of the Proctolabinae. 


\section{CHARACTERISTICS OF THE DISPERSAL CENTERS}

If the boundaries of the dispersal centers are superimposed on the map of the South American forest regions cirawn up by Huєck \& Seibert (1972), it becomes evident that the disparsal centers extend over several types of forests. However, if we consider the most important samples, except for those collected at the Guianan center, mainly one forest type is involved: type 6 for Napo, type 8 for Ucayali, and type 5 for Madeira.

Superimposition on a general map of the climates gives further indications: the Napo center appears to be located in a region of maximum rainiall, with a weak "less-rainy" period. The meridional centers (Ucayali and Madeira) are sharacterized by a less humid climate: lower rainfall, and a marked dry season often extending over about 3 months. The forests in these areas are, thus, less luxuriant and often interspersed with nonforest areas whose location depends on the nature of the soill.

The Guianan center is ecologically heterogeneous and extends over two different climatic regions separated by the mountains which delimit the center in the south (narrow sense of Müllər, 1973). The northern climate is somewhat more humid than the southern one, particularly in the regions of Manaus and Óbidos which are located in a broad, relatively dry zone that crosses the forest from the NW do the SE.

The faunistic characteristics of each center are related to the ecological particularities of their environment.

The Napo center, which is the most typical rain forest center, is also the richest in species; and this does not seem to be exclusively due to the fact that at the present time it is the best known center.

The ecological conditions of the meridional centers are, on the contrary, more favorable to less arboreal acridids that prefer more open biotepes.
Thus, the Madeira center is characterized by some Proctolabinae, often thamnophilous and having a polycentric distribution (Fig. 3) . The group borellii of the genus Eucephalacris includes 3 species, two of which are arboreal and vicariant (one know from the Guyanan center, the other found in the Rio Madeira and the Rio Purus regions). The third species, $E$. borellii, is adapted to open biotopes and is the most widely distributed Proctolabinae. Known from Paraguay to Óbidos and Porto Velho, it probably ranges over the entire Cerrado. This species is also found in the nonforest areas enclosed in the forest of the Madeira center.

The genus Cryptocloeus, a typical thamnophilous insect and secondary-formation dweller, is currently known to include 4 species which are diagonally distributed from Porto Velho to Cayenne; but it probably ranges more widely in the eastern part of the Amazonian basin.

Zodiacris rubidippennis is distributed over the Madeira center and reaches Suriname. The group modestus (2 species) of the genus Poecilocloeus has an analogous distribution pattern.

In the subfamily Proctolabinae, it is the fauna of this region which shows the strongest dispersal tendency, representing both the ecological characteristics of the Madeira center (less dense forest) and the behavioral particularities of the group.

The sizes of the gaps between the different taxons present in the dispersal area show that the changes which gave rise to them took place at different periods and were probably related is several expansions of a suitable vegetation (Prance, 1978).

Although the arboreal fauna of the Ucayali center is insufficiently known, the contours of the center were able to be delimited through the study of the Pactrophorinae and the Proctolabinae. However, the occidental part of this center is also characterized by its diversity of species of Ommatolampae ( ${ }^{4}$ ) (Fig. 4) and particularly by their abundant number. This latter group, comprised only of micropterous and

(4) - The group Ommatolampinae (Ommatolampinae) has been revised by Carbonell and Descamps, 1978. 
thamnophilous forms living in relatively low shrubs under the forest trees, is autochtonous to South America. Its species are uncommon in the northern centers and particularly in Guiana, but this group is quite diversified in the southwesturn part of the Ucayali center, where it recently gave rise to a great number of species. Ommatolampae are also comprised of highly differentiated genera which inhabit the eastern slope of the Andes from southern Peru and Bolivia to Equador.

Within this group, the genus Episomacris displays the most striking distribution pattern. Probably having a former widespread distribution, it now shows remnant isolated populations only in the Ucayali center, Guiana, Pernambuco, and to the south of Bahia (remnant forest island of the Atlantic Forest). This kind of discontinuous distribution appears to demonstrate the peculiar ecological characters of the Ucayali center, at least in its southwestern part, which now acts as a refuge for a regressing thamnophilous fauna, consecutive to the expansion of an unsuitable forest type. The previous forest, probably less dense, extended through the Amazon basin to the Atlantic coast.

The spreading of the Ommatolampae might be related to that of the Madeira Proctolabinae; but in the present type of vegetation, the latter, which are arboreal, are able to maintain a wider dispersal zone than the former which are micropterous and associated with shrubs.

Despite more diverse climatic conditions, the Guianan center harbours a highly distinctive fauna. This is particularly true for the Bactrophorınae which include, for 13 species, 4 endemic genera, while the Napo and Ucayali centers include only one genus for an uncomparatively higher number of species (94).

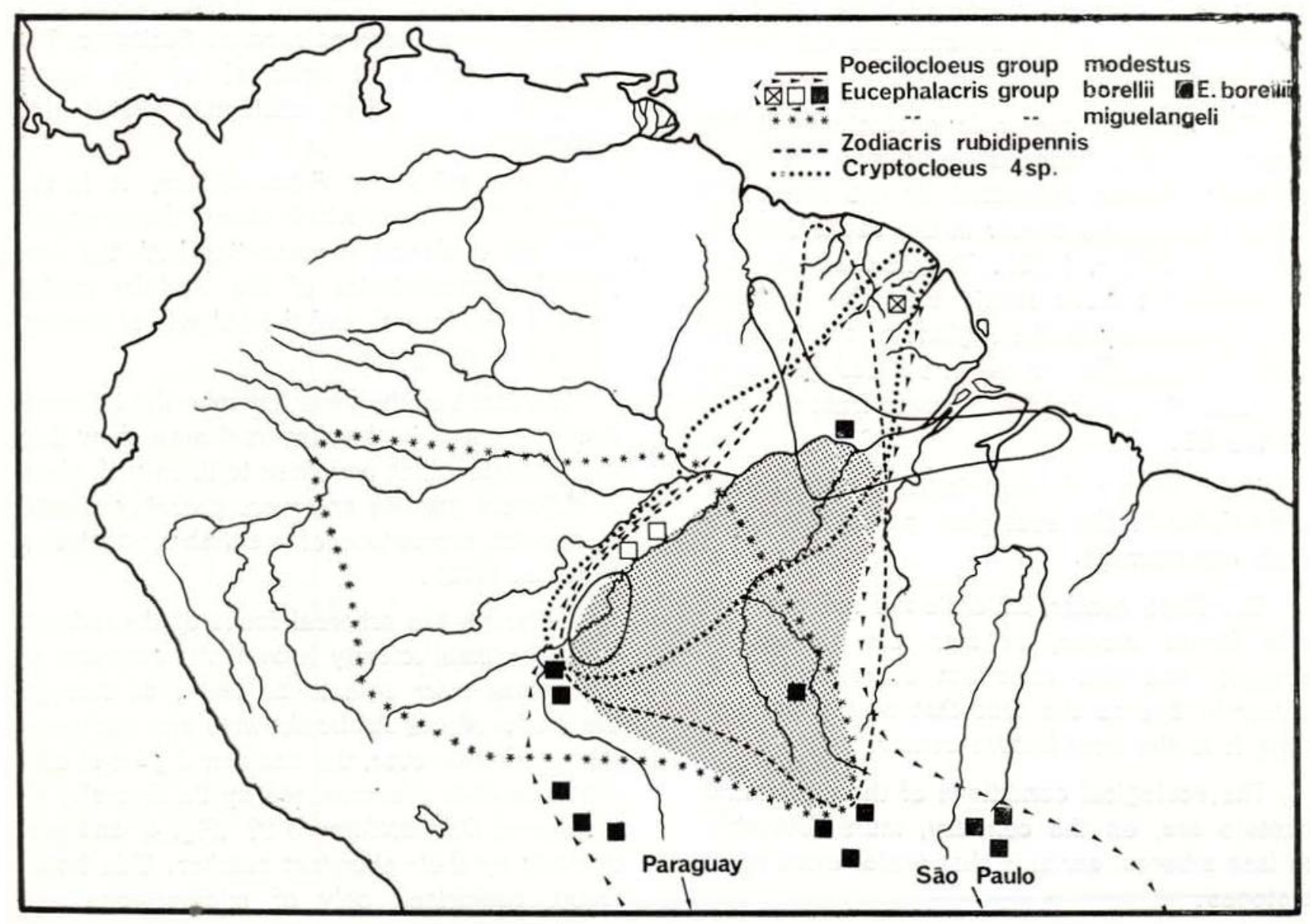

Fig. $3-$ Polycentric distribution of the madeira Proctolabinae. 


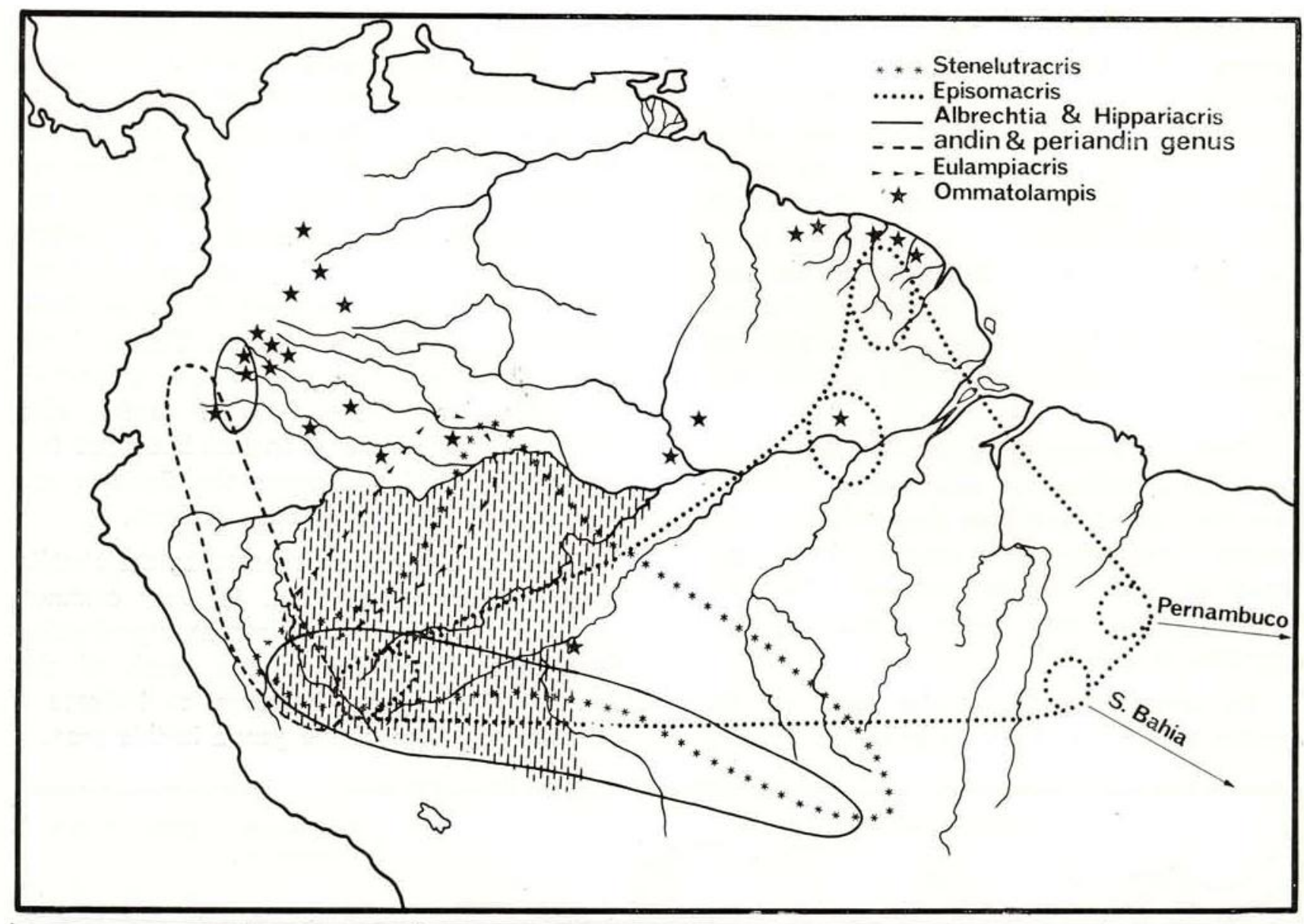

Fig. 4 - Polycentric distribution of the Ommatolampae (Ommatolampinac).

No endemic Bactrophorinae are known to occur in the Madeira center. It then seems reasonab!e to assume that this peculiar fauna is the consequence of a relatively ancient geographic isolation and that this part of South America was for a long time an active center of differentiation.

When analyzed in more detail, the 23 species and subspecies typical of the large Guianan center are shown to be distributed acco:ding to three patterns: 13 septentrional elements, 5 meridional, and 5 which range from the coast to the Amazon river and which represent approximately one quarter of the endemic fauna. This gives a slight indication that two subcenters, related either to both climates or separated by the mountains of Southern Guiana, possibly exist.

\section{RELATIONS BETWEEN THE AMAZONIAN CENTERS}

As shown by the Madeira Proctolabinae and the Ucayali Ommatolampae, the faunistic contacts between the two southern centers, the Guianan center and, incidentally, the Atlantic Forest were greatly facilitated in the recent past by the ecological environment.

The existence of a link between the northern and the southeastern centers, similar to, although weaker than that of the western centers (also considered as one large center that includes two subcenters, Napo and Ucayali) is indicated by several oriental distribution patterns. In addition to the groups dealt with in this paper, we can cite, for example, among the Caloscirtae (Ommatolampinae), the eastern genus Caloscirtus, vicariant of the western genera Calohippus and Eugenacris (Fig. 5). With regard to exchanges between the northern and the southwestern centers, we can cite Pseudomastax which has recently colonized the Napo center ( 3 species) and which came from the Ucayali center where it shows an xtraordinary diversification (19 species), especially in the vicinity of the Andes. 
Although more restricted than the relations between the southern, western, or eastern centers, relations between the northern centers do nontheless exist. Some Napc Bactrophorinae (Adrolampis, Pseudonautia) range to the north outside of the forest realm. They persist in the forest galeries of the llanos and reach the Venezuelan coast. One species. Adrolampis delicata, of the characteristic Napo "colom. biae" group is known from Guiana, while the Guyanan Adrolampis vittagenae reaches Maracay.

Similarly, among the group "colombiae" of the genus Pseudonautia, one species is known from the Colombian Caraib plain, while another inhabits the Guyanan center. It seems, therefore, that contact between the two northern centers was easier in the very near past than it is today.

No longer situated at the genus or the species level but at the tribe level, the peculiar distribution of the Taeniophorini (Bactrophorinae, (Fig. 6) has to be mentioned. This typical and well-diversified transandean tribe, until yet unknown south of the Amazon river includes only one species of the genus Taeniophora cominon in the secondary formations of the Napo center. On the contrary, 2 vicariant species of an arboreal atypical genus (Hylephilacris) inhabit the northern and the southern regions of the Guianan center. This endemic genus, an image of the highly distinctive characteristics of the Guianan center, also reflects the existence of ancient but close faunistic relationships between the Guianan and tive Central American-Andean regions.

Another case is represented by the chablis genus Ommatolampis (Fig. 4), very common north of the Amazon. A recent signalization from Porto Volho far to the south of the Amazon river seems, however, to indicate a relictual presence of the genus in this area.

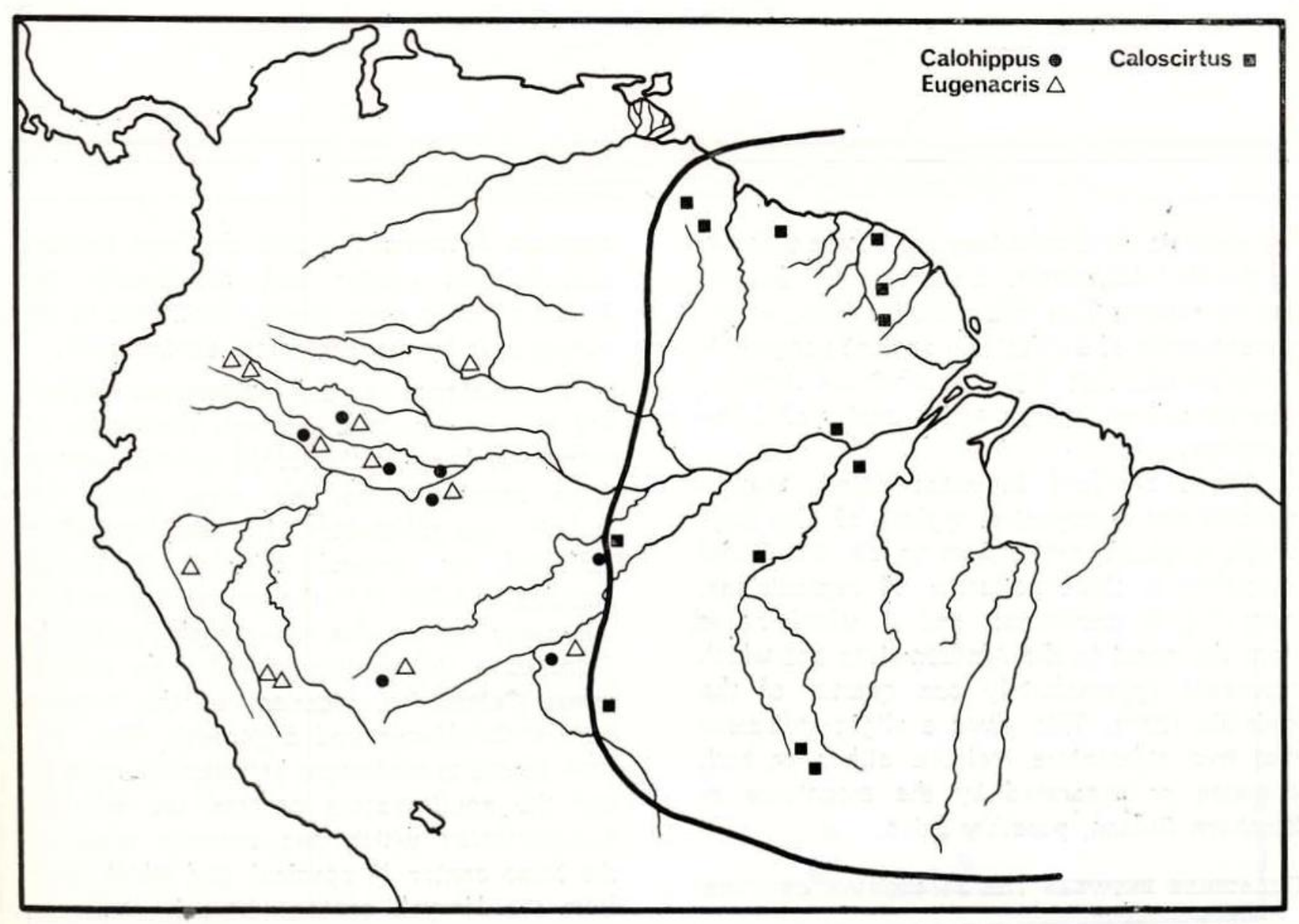

Fig. 5-Distribution of the genera Caloscirtus, Calohippus and Eugenacris. 


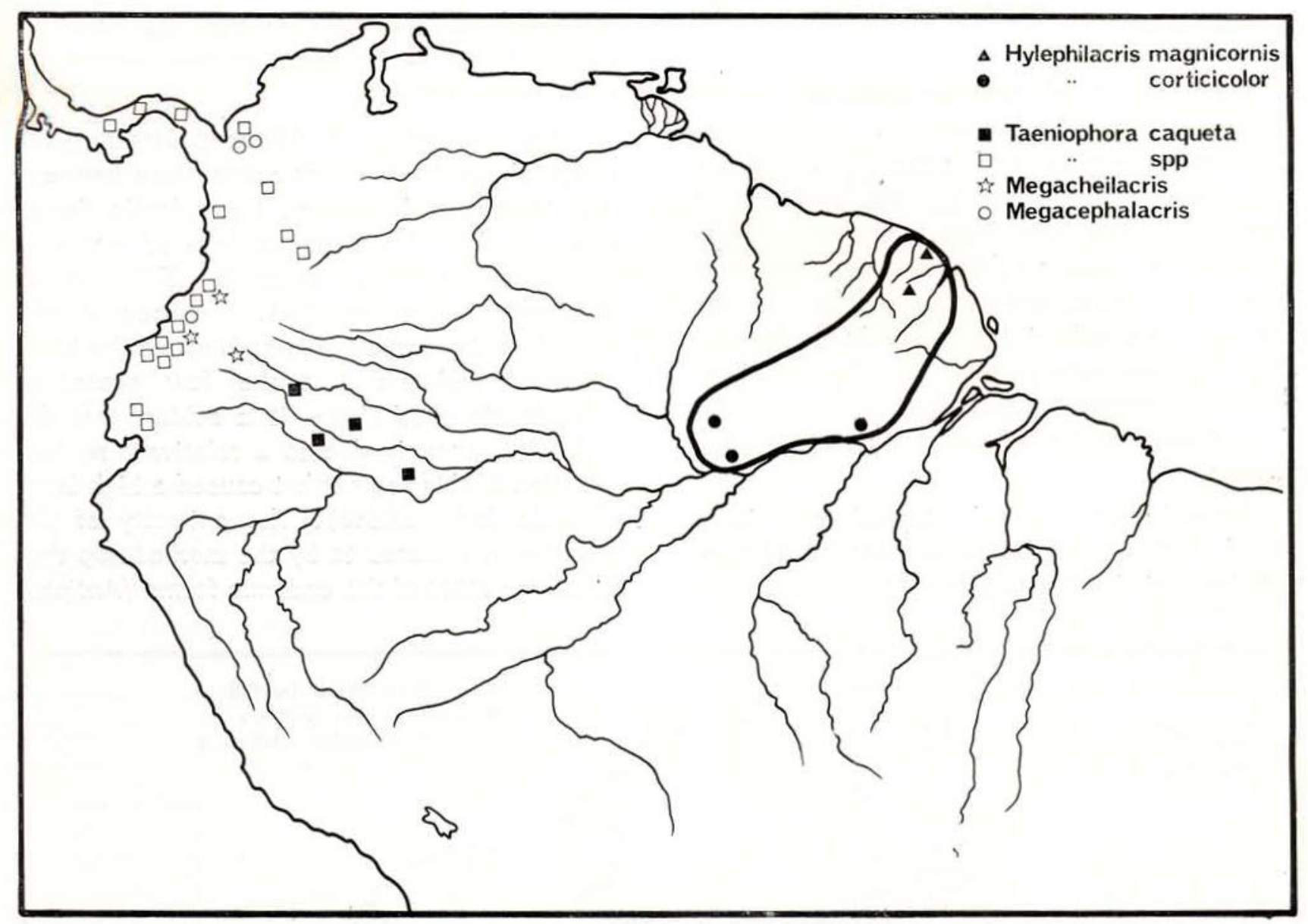

Fig. 6 - Distribution of the tribe Taeniophorini (Bactrophorinae).

\section{RELATIONS WITH THE ATLANTIC FOREST}

The arboreal fauna of the Atlantic Forest is very poorly known at the present time. Moreover, as a consequence of intense agriculture and breeding, any hope of cbtaining more knowledge about this region seems to be already lost.

Three arboreal species were recently discovered. Two of them, Adrolampis bahiana (Bactrophorinae) and Poecilocloeus janeirensis (Proctolabinae), are closely related to the Ucayali groups of species. The third, Pseudonautia beckeri from Bahia, belongs to a welldifferentiated group of the Madeira center.

All of these species probably recently reached the Atlantic coast through an expansion of the forest. They typically show how the meridional centers functioned as suppliers in a less-demanding forest fauna.

Although insufficiently investigated, the arboreal fauna of the Brazilian Atlantic coast seems to be very poor (a sample taken in the Belmonte region during the most favorable months - December-January - contained very few insects). These results agree with the general faunistic impoverishment observed along a west-east axis (at least for the groups considered here). Among the $201 \mathrm{sp}$ :cies considered, 94 Bactrophorinae and 57 Proctolabinae occur in the western centers as compared to 30 anci 20 respectively in the eastern centers.

This impoverishment is particularly striking in the genus Poecilocloeus for which, among the 47 known species, 40 inhabit the western centers, 6 the eastern centers, and only one is thought to be endemic in the Atlantic Forest. 


\section{CONCLUSIONS}

This study reveals that the dispersal centers are characterized by a relatively high number of endemic genera and species. Prevailing environmental conditions (climate and type of vegetation) also contribute to the faunistic originality of each of these centers. Possibly wide, but imprecisely defined zones of interpenetration reflect the faunistic exchanges which predominate between the two western centers, between the two eastern centers, and to a lesser extent between the meridional centers.

Some biogeographical and paleoclimatological hypotheses are confirmed by the characteristics and the interrelations of the different dispersal centers. This is the case for the refuge theory - for forest refuges as well as for savanna retuges.

The expansion of different forest types which allowed temporary connections between the Amazonian basin and the Atlantic Forest is affirmed by the presence there of recent or moderately ancient elements (Episomacris, Adrolampis, Pseudonautia). However, if one considers the entire regional fauna of the Mata Atlantica and not just the few accessory components cited above, it is evident that the major influence is due to a relatively ancient isolation of this region that caused a high level of endemism $(53,3 \%)$. The antiquity of the isolation is attested to by the marked gap that separates most of the endemic forms (Antipha-

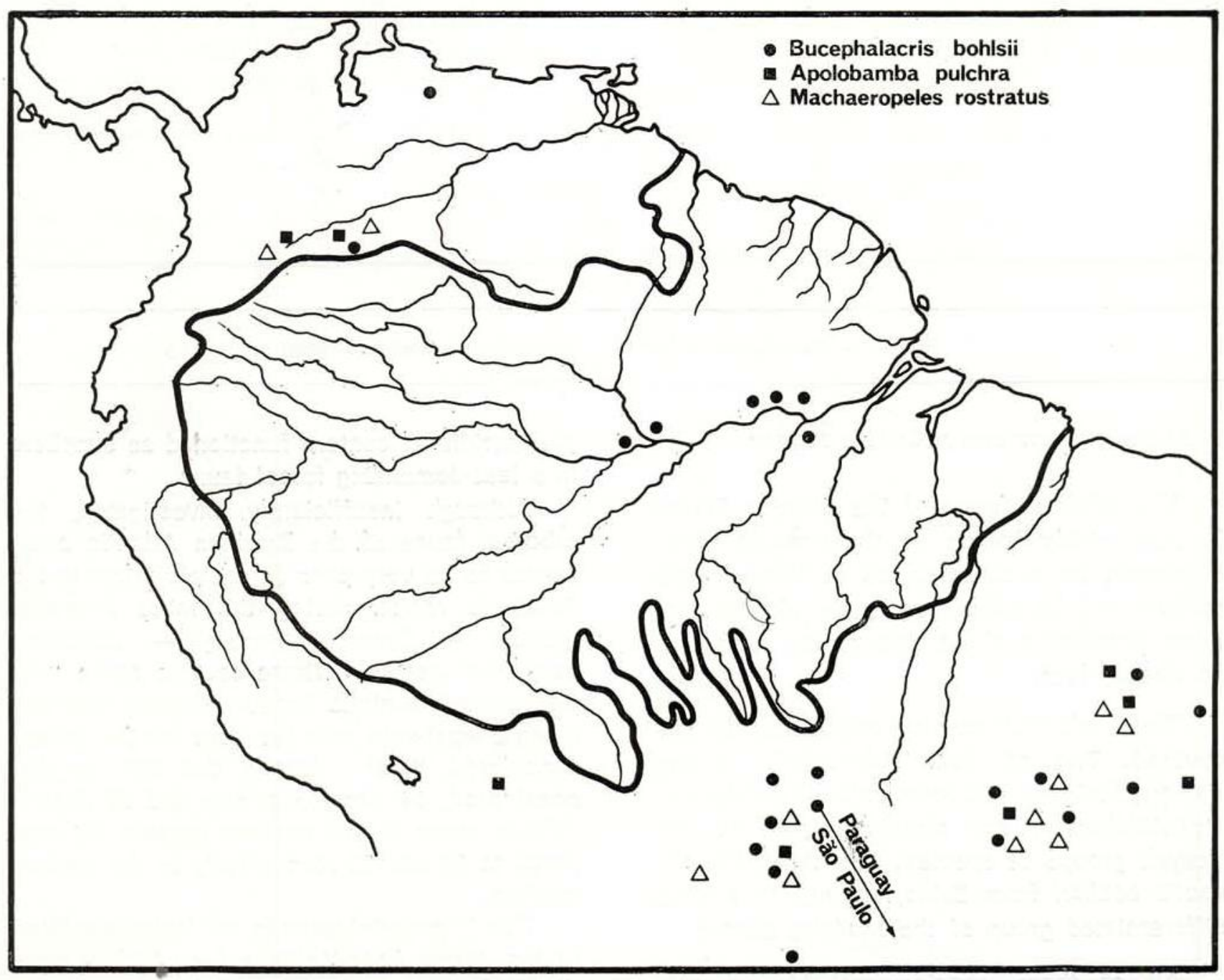

Fig. 7 - Transamazonian distribution of some open-biotope species. 
nes, Antiphon, Opshomala, Lathacris, Pycnosarcus, etc...) from their closest Amazonian relatives.

On the other hand, the recession of the forest allowed intermittent contact between the savannas which border the Amazonian forest to the north and to the south. This is attested to by some transamazonian distribution patterns, (Fig. 7). Three species still persist as evidence of one of the most recent connections: Apolobamba pulchra (Gomphocerinae), Bucephalacris bohlsii, and Machaeropeles rostratus (Ommatolampinae). These open-biotope species are widely distributed in the Cerrados, probably inhabiting all the region that extends from the Bolivian Llanos to the Caatinga. They are found again north of the Amazonian forest where one of them (Machaercpeles rostratus) is differentiated at the subspecies level. Bucephalacris boh/sii is also found in the "campos" areas enclosed in the forest and in the anthropic open-biotopes of Lower Amazonia.

\section{RESUMO}

Os centros de dispersão da fauna acridiana arbórea da Amazônia são definidos com base no estudo das Subfamílias Bactrophorinae e Proctolabinae. Foram revelados quatro centros de dispersão, os quais correspondem aos principais centros propostos por Müller (1973) e Haffer (1979). As características ecológicas de suas faunas e as relações entre os centros são abordadas provisoriamente através do estudo de alguns padrões de distribuição policêntrica (Ommatolampinae, Proctolabinae), assim como através de relações mais restritas entre os centros amazônicos e a Mata Atlântica.

\section{REFERENCES}

AMÉDÉGNATO, C.

1977 - Etude cies Acridoidea centre et sud ameri. cans (Catantopinae, sensu lato): anatomie des genitalia, classification, répartition, phy. logénie: Thèse de doctorat, Paris .

AMÉDÉGNATO, C. \& DESCAMPS, M.

1981 - Etude comparative de qualques peuplements acridiens de la forêt néotropicale. Acrida 9 (4): $1-216$

CARBONELL, C.S. \& DESCAMPS, M.

1978 - Revue des Ommatolampae (Acridoidea, Om matolampinae). Annls Soc. ent. Fr., (N.S) 14 (1): $1-85$.

DESCAMPS, $M$.

1976 - La faune dendrophile néotropicale. I. Re. vue des Proctolabinae (Orth. Acrididae). Acrida E (2): 63-167.

1978 - La faune dendrophile néotropicale. II. Revue des Taeniophorini et Ophthalmolampini (Orth. Romaleidae). Bull. Mus. natn. Hist. nat., 3ème série n. ${ }^{\circ}$ 517. Zool. 355: 371-476.

1980 - La faune dendrophile néotropicale. V. Second revue des Proctolabinae amazoniens et guyanais (Orth. Acrididae). Annls. Soc. ent. Fr. (N.S.) 16 (1): $19-47$ et 16 (2): 161 195.

s/d - La faune dendrophile néotropicale. Seconde revue des Ophthalmolampini. (in press).

HAFFER, J.

1979 - Quaternary Biogeography of tropical lowland south America, Univ. Kansas Mus. nat. Hist. Monogr. 7: 106-140.

HUECK, K. \& SEIBERT, P.

1972 - Vegetation karte von Südamerika. Gustav Fisher Verlag. Stuttgart.

MOLLER, P.

1973 - The dispersal centers of terrestrial vertebrates in the neotropical realm. Dr. W. Junk B.V., publishers, the Hague. 244p.

PRANCE, G.T.

1978 - The origin and evolution of the amazon flora. Interciencia, 3 (4): 207-222.

(Aceito para publicação em 26/01/82) 